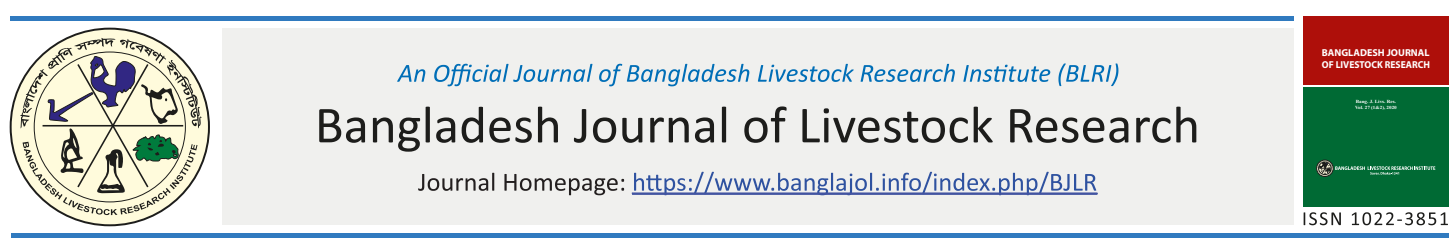

\title{
Ovarian physiology of repeat breeder cows at Bathan area of Bangladesh
}

\author{
M.Y. Ali ${ }^{1 *}$, M. Ershaduzzaman ${ }^{1}$, R. Khatun ${ }^{1}$, U. S. Alam ${ }^{1}$, S.Akter ${ }^{3}$, R.R. Roy ${ }^{3}$, M.A.Habib ${ }^{1}$, \\ S. Munira ${ }^{1}$ J. M. Esha ${ }^{2}$ and N.R. Sarker ${ }^{1}$ \\ ${ }^{1}$ Bangladesh Livestock Research Institute, Savar, Dhaka-1341, Bangladesh \\ ${ }^{2}$ Department of Genetics and Breeding, Bangladesh Agricultural University, \\ Mymensingh-2202, Bangladesh \\ ${ }^{3}$ Department of Livestock Services, Central Cattle Breeding and Dairy Farm, Savar, \\ Dhaka-1341, Bangladesh
}

\begin{abstract}
The experiment was implemented at farmer's house and Bathan areas of Shahjadpur Upazila in Sirajganj and Bera Upazila under Pabna districts of Bangladesh. The aim of the study was to know the incidence of repeat breeding (RB), physiology of different follicles and deformity of ovary and uterus in Holstein Frisian (HF) cows. Forty (40) RB HF cows ( $>50 \%$ HF Genetic) were selected on the basis of age and parity. Pyometra, endo-metra, cervicitis, Salpingitis and tumor like growth etc. in uterine wall were observed. Luteal and follicular cyst was also identified. Number of growing follicle appeared ultrasonically, size of Graafian follicle, breed, cow's body size, and inheritance level and parity, nutritional factors and days calving to first service were recorded properly. All collected data were statistically analyzed by the SPSS soft-ware program using completely randomized design $(\mathrm{CRD})$. Results revealed that, significantly $(\mathrm{P}<0.05)$ highest Body Condition Score (BCS) was 3.47 \pm 0.05 observed in the cows of group-D whose age were more than 8 years of old compared to others group (table 1). In-case of average daily milk yield and remained dry condition differences were highly significant $(\mathrm{P}<0.001)$. Maximum milk yield $(20.41 \pm 0.821 /$ day $)$ was observed in group-C compared to others group but minimum dry condition remaining period was observed in group-A than others. Days of heat showed number of AI service were non-significant $(\mathrm{P}>0.05)$ in the whole experiment (table-1). The percentage of infection (Pyometra, Endometra) in the uterine wall differed non-significantly ( $\mathrm{P}>0.05)$ among all the groups and minimum occurrence were observed in group-A (figure 1). Highest percent of cyst observed in the right ovary than left of the cows of group-D compared to others group but the differences were non-significant $(\mathrm{P}>0.05)$. Comparatively higher percentage $(58.82 \pm 12.30)$ of follicles observed in left ovary of group-D than right ovary of others group (table 3$)$. Non-significantly $(\mathrm{P}>0.05)$ the highest average number $(2.40 \pm 0.44)$ of follicles was observed in left ovary of the group-C than the cows of others group. Though the follicle size in the end of luteal phase differed non-significantly $(\mathrm{P}>0.05)$ but comparatively larger $(14.90 \pm 1.54 \mathrm{~mm})$ follicle in diameter were observed in group-C, than the follicles of others groups.
\end{abstract}

Key words: RB, OFC, Uterine Infection, Diameter, Follicle

Bang. J. Livs. Res. Vol. 27 (1\&2), 2020: P. 95-104. https://doi.org/10.3329/bjlr.v27i1.55173

\section{Introduction}

Baghabari is one of the most economically important place for milk production and it meets up two-third demand for milk of the

*Corresponding author: 113yousuf.bau@gmail.com 
whole country (Mohammed et al., 2017). The farmers of these areas rear about $98 \%$ crossbred cows and most of the cows are Holstein Friesian (HF) x Local crossbred. Their conception rate is $50-60 \%$ and require 1-3 insemination for a conception (Mohammed et al., 2017). In most cases, repeat breeding in cows are responsible for poor conception rate. About 29 percent dairy cattle in the Baghabari milk shed areas are repeat breeder (Mohammed et al., 2017). Khair et al. (2013) stated that Repeat Breeding (RB) directly influences the reproductive performance of dairy cows. The prevalence of $\mathrm{RB}$ in cows varied in different places in Bangladesh like $11.5 \%$ (Asaduzzaman et al., 2016) and 22.3\% (Hasan et al., 2017) and 29\% in Baghabari Milk shed areas of Bangladesh (MS Islam et al. 2018) . In Swedish dairy farm occurrence of RB is about 10\% (Gastafsson and Emanuelson et al. 2002). . RB is a multi factorial problems and increased production cost(Tk. 11051 /farm/year) in dairy farm through increasing insemination, treatment, feed, labour and management cost (Ali et al., 2013), increase calving interval, culling rates and decreased calf and milk production (Lafi et al., 1992). Variation of the hormonal constituents of the animal body has been reported for the reproductive failure (Adler et al., 2009, Lequin. 2005). Uterine infection, inheritance and hormonal imbalance may lead to RB(Asaduzzaman et al., 2016).Many scientists observed others risk factors of $\mathrm{RB}$ like age, parity, BCS, milk yield(Asaduzzaman 2016, Islam et al ., 2012), physiological status ,milk yield, feed ( Nath et al., 2014). Pesánteza et al. (2016) reported that ovarian follicular cysts (OFC) in dairy cattle cause economic losses as a result of extension of the open period, cost of treatment, and risk of elimination of cows from the herd. OFC incidence risen with increasing milk production and in these conditions, between 15 to $30 \%$ of cows develop this ovarian condition within 60 days postpartum (Peter, 2004). Cystic ovarian disease (COD) is responsible for frequent reproductive failure in cattle, resulting in significant economic losses for the dairy industry and COD incidence within dairy farms is variable, ranging between 5 and $25 \%$, which is most likely due to different management strategies (Silviu Ionut BORȘ et al., 2018). This disease is characterized by the failure of a mature follicle to ovulate at the appropriate time during the estrous cycle (Ortega, et al., 2015). Conception rate in cows might be fluctuated due to the O-cyte problems (Britt, 1994). Follicular diameter at specific stage of estrus cycle generally plays a vital role in the fertilization/conception rate (Meneghetti et al ., 2009). Busch et al . ( 2008) stated that most favorable size of ovulatory follicles is still a chief apprehension in beef and dairy farming (Vas concelos et al., 2013, Bisinotto et al ., 2014). The higher follicular diameter significantly increases the pregnancy /conception rate (Perry et al., 2005). Although global scientific literature offers outstanding reviews and original articles about RB and OFC, to our knowledge, there are very little scientific studies describing their clinical presentation in a herd. That's why this study was undertaken with the objective to identify the uterine infections, ovarian physiological features of Holstein Friesian RB cows in the selected areas.

\section{Materials and Methods}

\section{Location of the experiment}

The experiment was implemented at farmer's 
house and Bathan areas of Shahjadpur and Bera under Sirajganj and Pabna district of Bangladesh. The areas located at the northern part of the country under Sirajganj $\left(23^{\circ} 41^{\prime} \mathrm{N}-90^{\circ} 20^{\prime} \mathrm{E}\right)$ and Pabna $\left(24^{\circ} 00^{\prime}\right.$ $\mathrm{N}-89^{\circ} 10^{\prime} \mathrm{E}$ ) district of Bangladesh (which known as milk pocket area of Bangladesh). About two-third of cattle reared and most of them are crossbred of Holstein Friesian (HF) with indigenous cattle.

\section{Grouping of animals}

There were forty $(n=40)$ Holstein-Freisian ( $>50 \%$ Blood) repeat breeding (RB) Cows of 02 to 08 years-old were randomly selected for this study. A herd comprising 10 cows at farmer's house and another 30 cows at Bathan areas were maintained under this study. They were divided in to four groups on the basis of age like A (2-4 years), B (5-7 years), C (7-8 years) and D ( $>8$ years). All RBC were marked by ear tag and maintained breeding record by Cattle Herd Book. These animals had an average number of service required for conception were 5.79 to 8.67 no per conception.

\section{Measurement of body condition score (BCS)}

The body condition score (BCS) implied the nutritional and health status of the selected cows and were scored considering the following grades using the lumber vertebral process (LVP) as described by Rahman (et al.1996), like as, Grade 1: cows had so much muscle that LVP not only invisible but also difficult to palpate, Grade 2: LVP not visible but easily palpable, Grade 3: only the head of LVP visible from close distance and easily palpable, and Grade 4: LVP clearly visible even from long distance with rough hair coat and thin back muscle (Hasan et al, 2018).

\section{Measurement of the ovarian follicular diameter}

The examination of ovaries and follicular diameter (FD) were measured in the selected cows initially by rectal palpation. Finally at days 10 of the estrous cycle the ovarian follicles were visualized by ultrasonography machine (Dus 60 Vet, Edan,USA). The feces were removed from the rectum, cleaned and the surrounding areas of vulva and rectum were swabbed with disinfectant to prevent infection in the reproductive tract. The ovary was grasped by inserting left hand through the rectum and the follicles were visualized by inserting a sectorial probe through the vagina. Before inserting the probe, it was disinfected by swabbing with $70 \%$ alcohol. Follicle numbers were recorded by counting on the screen of ultrasonography machine. The diameters of follicles were recorded by measuring length and breadth of each follicle on the screen (Figure 2). All visible follicles (>2.0 mm) were counted and recorded. The follicles were measured 3 times at a 3-day interval period without considering the stage of the reproductive cycle of the experimental animals (Deb et al. (2018).

\section{Data recording}

Oestrus detection was performed by monitoring the daily oestrus behaviour of the selected animals, 3 times each day for 30 minutes. After selecting the RB cows, infection like Pyometra, Endometra, Cervicitis, Salpingitis and Tumor like growth among others in uterine wall were identified with the help of modern veterinary approaches (Ultrasound machine). The status of ovarian follicles was observed at 10th day of estrous cycle. Finally, the ovaries were examined for 
presence or absence of Luteal and follicular cysts. Ultrasound scan with a $5 \mathrm{MHz}$, linear-array, vaginal transducer was used, obtaining static images. The ovulatory follicles were studied on day 0 - the first day of study $(n=18)$ and until those formed during the following cycle $(n=22)$. Follicle size, location right ovary/left ovary (RO/LO), and number of follicles per ovary were studied in all studied cows. The following parameters were evaluated: the examination day, day of maximum size, period of follicular growth and follicular atresia and atresia rate. Moreover, cows body size, and inheritance level and parity, nutritional factors, heat stress (record temperature and Relative Humidity at the time of estrus), days calving to first service and different reproductive diseases were recorded properly.

\section{Statistical analysis}

Data from the measurement values of FD, uterine infection and cysts were entered into Microsoft Excel-2007 work sheet and analyzed by SPSS software version 20 using descriptive statistics. Continuous data from the ovarian, reproductive and productive physiological characteristics of RB cows were analyzed following principle of ANOVA.

\section{Results and Discussion}

\section{Productive physiology of $R B$ cows}

The productive characteristics of the selected cows are presented in Table 1. Results showed that average milk production was higher $(\mathrm{P}<0.001)$ in group $\mathrm{C}$ (20.41 \pm 0.82$)$, than all the others groups (A, $\mathrm{B}$ and D) and lower (15.27 \pm 0.76$)$ in group B compared to others groups. Present findings resembled with the findings of Hasan et al. (2018).Similarly Hasan et al., (2017) stated that higher repeat breeding syndrome(RBS) was found in cows having higher milk production and lactation period. However, the number of services per conception increases in high-yielding cows due to changes in reproductive physiology (Royal et al., 2000). Furthermore, it was also reported that an increasing milk production and higher lactation length are found to be risk factors for being an RB (Gustafsson and Emanuelson, 2002) and RBS increases in cows due to higher milk yield in Bangladesh (Asaduzzaman et al., 2016). Table 1 results also showed that significantly $(\mathrm{P}<0.01)$ higher BCS observed in group D (3.47 \pm 0.05$)$ compared to others groups (Hasan et al., (2018) but did not found positive relationship with repeat breeding in cows.

Table 1: Phenotypic parameter of repeat breeder cows

\begin{tabular}{l|c|c|c|c|c|c}
\hline \multirow{2}{*}{ Parameter } & \multicolumn{4}{|c|}{ Group (Mean \pm SE) } & P & Level of \\
\cline { 2 - 6 } & $\begin{array}{c}\mathrm{A}(2-4 \\
\text { years })\end{array}$ & $\begin{array}{c}\mathrm{B}(5-7 \\
\text { years })\end{array}$ & $\begin{array}{c}\mathrm{C}(7-8 \\
\text { years })\end{array}$ & $\begin{array}{c}\mathrm{D}(>8 \\
\text { years })\end{array}$ & Value & significance \\
\hline $\mathrm{BCS}(0-5)$ & $2.94 \pm 0.17$ & $3.00 \pm 0.14$ & $3.22 \pm 0.06$ & $3.47 \pm 0.05$ & 0.01 & $*$ \\
\hline Milk yield(liter/day) & $18.15 \pm 1.52$ & $15.27 \pm 0.76$ & $20.41 \pm 0.82$ & $20.06 \pm 0.94$ & 0.00 & $* *$ \\
\hline Dry period (month) & $20.66 \pm 1.36$ & $31.07 \pm 1.32$ & $30.27 \pm 1.12$ & $30.23 \pm 1.98$ & 0.00 & $* *$ \\
\hline $\begin{array}{l}\text { Interval between } \\
\text { two estruses (days) }\end{array}$ & $31.50 \pm 6.91$ & $47.56 \pm 7.71$ & $44.90 \pm 4.11$ & $41.47 \pm 9.28$ & 0.71 & NS \\
\hline Service given (No) & $8.67 \pm 1.95$ & $6.74 \pm 0.95$ & $5.79 \pm 0.62$ & $8.18 \pm 2.34$ & 0.37 & NS \\
\hline
\end{tabular}




\section{Uterine Infection}

There were no statistical variation of infection in the uterine wall with minimum $(22.22 \pm 14.69 \%)$ in group A and maximum $(29.41 \pm 11.39 \%)$ in group D (Figure 1). The animals of group A, having 2 to 4 years of age which is smaller than that of others groups whose age $>4$ years of old. It is very conceivable that as a cow gets older and parity increases, the uterine tissue becomes senile and the organ becomes more prone to infections and ultimately increasing the low conception rate in dairy cows (Hassan et al., 2017). Correspondingly, Bonneville-Hébert et al. (2011) reported that the RB syndrome increases if the cow has per- partum reproductive problem and also increases with parity (Hassan et al., 2018). So it is clear that with the increases of age there will be increased the incidence rate of $\mathrm{RB}$ syndrome in cows.
The results of our experiment in table 2 reviled the percentage of Ovarian Follicular Cyst (OFC) through Ultrasonography in both ovaries. There was no statistical variation of cysts percentage among the groups (table-2). Whole the experiments the percentage differences of OFC among the groups were non-significant $(\mathrm{P}>0.05)$. JL Pesánteza et al., 2016 observed that the incidence rate of follicular Cyst 23\% in Swedish dairy farm, which slightly more than our findings $(11.11 \pm 5.11)$ of group $-\mathrm{A}$, but smaller than Group- D $(70.59 \pm 11.39)$. Our observed values, consistent with other observations in comparatively better conditions (Melendez et al., 2003, Vanholder et al ., 2006), contrasts with the findings (1 to $16 \%$ ) recorded in the 1980s, (Kesler and Garverick 1982, Bartlett et al., 1986) which were more similar. The differences in the incidence of Cystic Ovarian Follicle (COF)

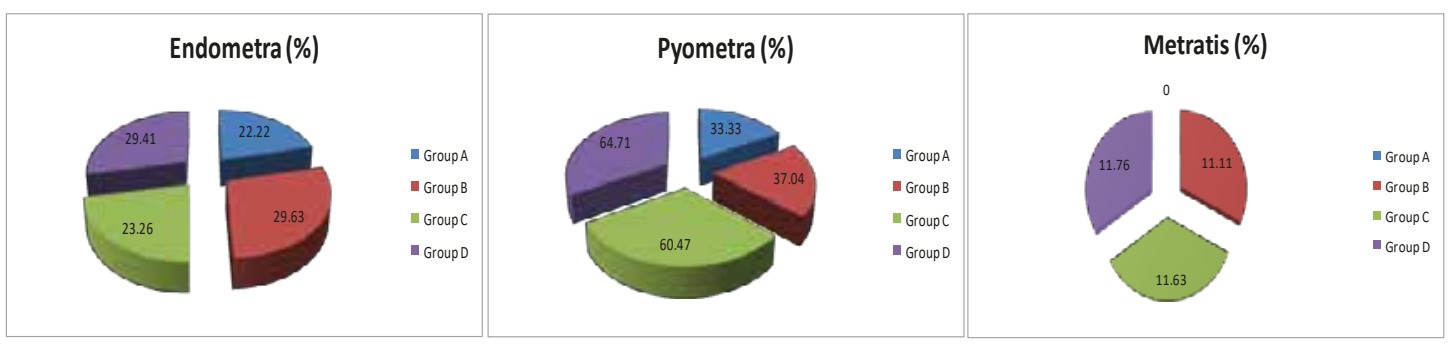

Figure 1: Percentage of uterine infection incidence in RB cows

\section{Ovarian Follicular Cyst}

Different researchers stated the appearance of OFC in different ways among them Kesler et al. 1981 described OFC as may be observed as thin-walled, fluid filled structures on one or both ovaries and be associated with high plasma estradiol but Farin and colleagues (1992) described the appearance of follicular cysts on ultrasound screens as "an anechoic antrum and a smooth, thin wall with few or no gray patches. may due to the parity number because Group A contained the cows whose age ranged from 2 to 4 years where as Group D possessed more than 8 years old. Short and irregular estrus and age were regarded as the major clinical signs of cows with OFC; in this study, however, cows diagnosed with OFC were submitted to reproductive examination due to absence of estrus or failure to return to estrus after insemination. 
Table 2: Cysts presented (\%) of repeat breeder cows

\begin{tabular}{l|c|c|c|c|c|c}
\hline \multirow{2}{*}{ Parameter } & \multicolumn{4}{|c|}{ Group(Mean \pm SE) } & $\begin{array}{c}\text { P } \\
\text { Value }\end{array}$ & $\begin{array}{l}\text { Level of } \\
\text { significance }\end{array}$ \\
\cline { 2 - 6 } & $\begin{array}{c}\mathrm{A} \\
(2-4 \text { years })\end{array}$ & $\begin{array}{c}\mathrm{B} \\
(5-7 \text { years })\end{array}$ & $\begin{array}{c}\mathrm{C} \\
(7-8 \text { years })\end{array}$ & $\begin{array}{c}\mathrm{D} \\
(>8 \text { years })\end{array}$ & & \\
\hline $\begin{array}{l}\text { Ovarian } \\
\text { follicular cyst in } \\
\text { right ovary (\%) }\end{array}$ & $66.67 \pm 16.66$ & $48.15 \pm 9.79$ & $48.84 \pm 7.71$ & $70.59 \pm 11.39$ & 0.35 & $\mathrm{NS}$ \\
\hline $\begin{array}{l}\text { Ovarian } \\
\text { follicular cyst in } \\
\text { left ovary (\%) }\end{array}$ & $11.11 \pm 5.11$ & $14.81 \pm 6.96$ & $23.26 \pm 6.51$ & $17.65 \pm 9.53$ & 0.76 & $\mathrm{NS}$ \\
\hline
\end{tabular}

$\mathrm{NS}=$ Non significant

\section{Evaluation of follicles}

The results obtained from Ultrasonography (EDAN Dus-60) examination of RB Cows presented comparatively higher average percentage of follicles $(58.82 \pm 12.30)$ in the left ovary of group-D than the right ovary of the animals of others groups (A, B and C) in the whole duration of the experiment (Table $3)$. The highest average number $(2.40 \pm 0.44)$ of follicles were observed in left ovary of the cows of group-C than others group but the differences were non-significant $(\mathrm{P}>0.05)$. The follicle size at 10th days of estrus cycle differed non-significantly $(\mathrm{P}>0.05)$ but comparatively larger $(14.90 \pm 1.54)$ follicle in diameter was observed in group- $\mathrm{C}$, than the follicles of the cows of others groups.

During our study we considered large, medium and small follicles in the ovary under Ultrasonography examination a few of them represented large follicles which was taken under our main consideration. The average numbers of follicles according to their size and ovarian positions were given in table 3. Numbers of small follicles per ovary in our experimental cows were more or less similar to GK dab et al (2018). In general majority of the follicles were small to medium in cows (GK dab et al, 2018). On the contrary Hasan et al 2018 observed in RB Holstein Friesian Cows the largest follicles size $9.62 \pm 2.37$ and in normal cows was $13.79 \pm 2.14$. The largest follicles found in our experiment in RB cows slightly larger than found Hasan et al 2018. The number of follicles in an ovary did not vary $(\mathrm{P}>0.05)$ between right and left ovary of RBC. In general the size of follicle depends on many factors and hormonal status as well as stage of estrus cycle (Figure 2). Follicle numbers and sizes continuously and considerably oscillate during the cycle due to wave-like development pattern in cattle (Adams et al., 1992). 
Table 3: Physiological parameter of the reproductive tract and ovaries of repeat breeder cows

\begin{tabular}{|c|c|c|c|c|c|c|}
\hline \multirow[t]{2}{*}{ Parameter } & \multicolumn{4}{|c|}{ Group(Mean \pm SE) } & \multirow{2}{*}{$\begin{array}{c}\mathrm{P} \\
\text { Value }\end{array}$} & \multirow{2}{*}{$\begin{array}{l}\text { Level of } \\
\text { significance }\end{array}$} \\
\hline & $\begin{array}{c}\text { A } \\
\text { (2-4 years) }\end{array}$ & $\begin{array}{c}\mathrm{B} \\
(5-7 \text { years })\end{array}$ & $\begin{array}{c}\mathrm{C} \\
\text { (7-8 years) }\end{array}$ & $\begin{array}{c}\mathrm{D} \\
(>8 \text { years })\end{array}$ & & \\
\hline $\begin{array}{l}\text { Measurable } \\
\text { follicles in right } \\
\text { ovary }(\%)\end{array}$ & $33.33 \pm 16.66$ & $25.93 \pm 8.59$ & $37.21 \pm 7.45$ & $11.76 \pm 8.05$ & 0.26 & NS \\
\hline $\begin{array}{l}\text { Measurable } \\
\text { follicles in left } \\
\text { ovary }(\%)\end{array}$ & $44.44 \pm 17.56$ & $29.63 \pm 8.95$ & $37.21 \pm 7.45$ & $58.82 \pm 12.30$ & 0.27 & NS \\
\hline $\begin{array}{l}\text { Follicles in right } \\
\text { ovary (no) }\end{array}$ & $2.00 \pm 0.80$ & $2.00 \pm 0.52$ & $2.40 \pm 0.44$ & $1.33 \pm 0.80$ & 0.31 & NS \\
\hline $\begin{array}{l}\text { Follicles in left } \\
\text { ovary (no) }\end{array}$ & $1.67 \pm 0.70$ & $0.85 \pm 0.46$ & $0.90 \pm 0.38$ & $1.00 \pm 0.70$ & 0.38 & NS \\
\hline $\begin{array}{l}\text { Largest follicular } \\
\text { diameter (mm) }\end{array}$ & $13.50 \pm 1.04$ & $10.50 \pm 0.53$ & $14.90 \pm 1.54$ & $10.60 \pm 0.67$ & 0.17 & NS \\
\hline
\end{tabular}

NS= Non significant
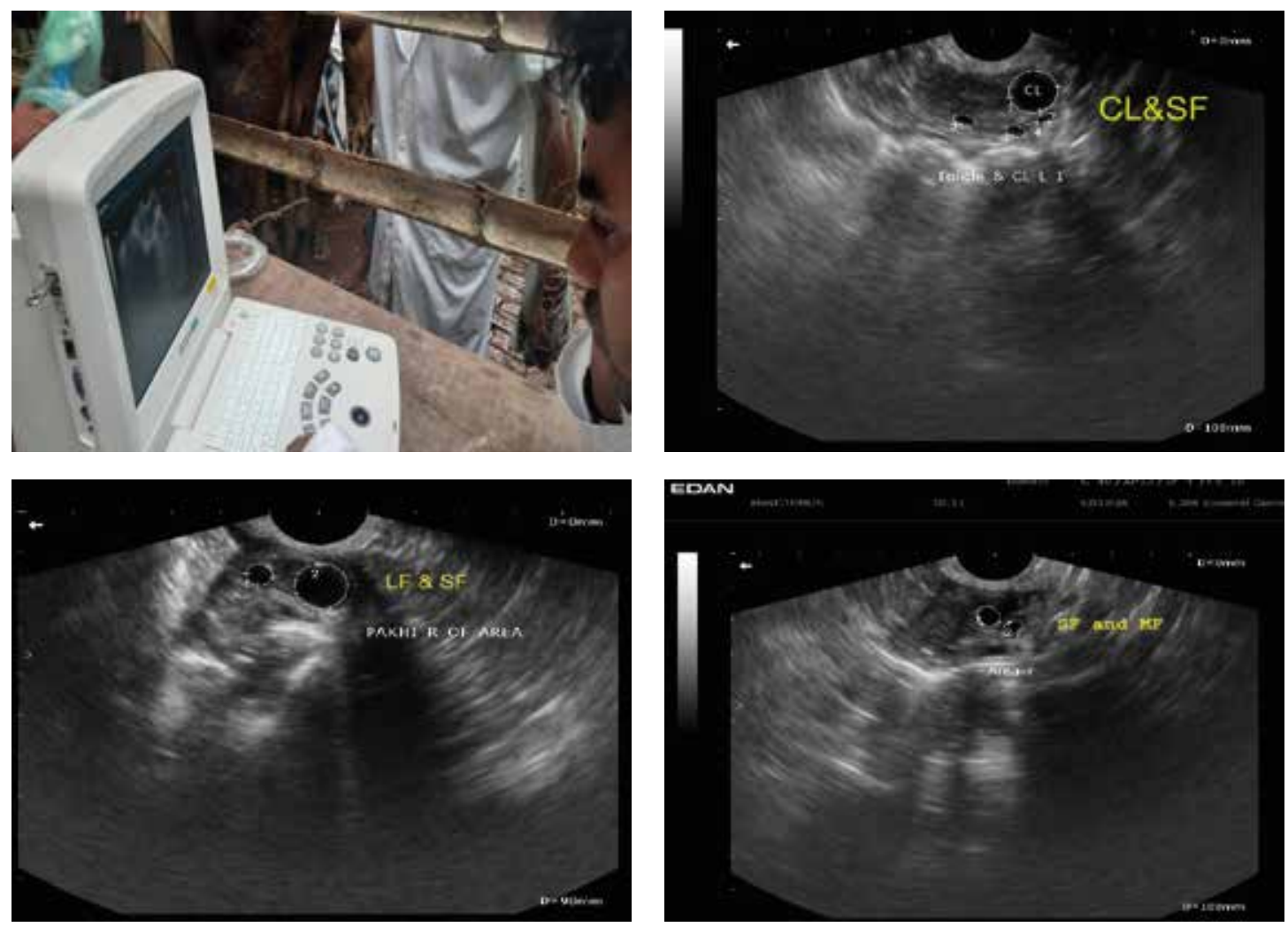

Figure 2: Different images of follicle and CL on the screen of Ultra sound machine 


\section{Conclusion}

It is concluded as, the present study developed guide line information on ovarian follicular size, cystic status and physical condition of RB cows that may be associated with repeat breeding in cows. Different types of follicles more or less evenly distributed in both ovaries, although large number of follicles and follicular diameter are higher in left ovaries. This information will be helpful for the researcher as well as the veterinary personal for early detection and treatment of repeat breeder cows.

\section{Acknowledgement}

The author feels proud to express his deepest sense of gratitude and profound appreciation to all the farmers for their help and Bangladesh Livestock Research Institute for financial supports to complete the research

\section{References}

Adams, G.P., Matteri, R.L., Kastelic, J.P., Ko, J.C.H., Ginther, O.J. 1992. Association between surges of follicle stimulating hormone and the emergence of follicular waves in heifers. J.Reprod. Fertil, 94: 177-188.

Adler., Michael., Schulz., Sven., Spengler and Mark. 2009. Cytokine quantification in drug development: a comparison of sensitive immunoassay platforms. Chimera Biotec $\mathrm{GmbH}$, Dortmund - Germany, Report Retrieved on $01 / 26 / 2010$.

Asaduzzaman, K.M., Bhuiyan, M.M.U., Rahman, M.M., Bhattacharjee, J.2016. Prevalence of repeat breeding and its effective treatment in cows at selected areas of Bangladesh. Bang. J. Vet.Med. 14(2):183-190.
Bartlett, P.C., Ngategize, P.K., Kancene, J.B., Kirk, J.H., Anderson, S.M. and Mather, E.C. 1986. Cystic follicular disease in Michigan Holstein-Friesian cattle: incidence, descriptive epidemiology and economic impact. Prev .Vet Med. 4, 15-33.

Bisinotto, R.S., Ribeiro, E.S. and Santos, J.E. 2014. Synchronisation of ovulation for management of reproduction in dairy cows. Animal.8(1):151-159.

Bonneville-Hébert, Ariane; Bouchard, Emile; Tremblay, Denis Du; Lefebvre, Réjean,2011.Effect of reproductive disorders and parity on repeat breeder status and culling of dairy cows in Quebec. Canadian Journal of Veterinary Research, 75( 2): 147-151.

Britt, J.H. 1994. Follicular development and fertility: potential impacts of negative energy balance. Proceedings, National Reproduction Symposium, Pittsburgh, PA. American Association of Bovine Practitioners, Auburn, AL.; 103-112.

Busch, D.C., Atkins, J.A., Bader, J.F., Schafer, D.J., Patterson, D.J., Geary, T.W. and Smith, M.F. 2008. Effect of ovulatory follicle size and expression of estrus on progesterone secretion in beef cows. Journal of Animal Science.; 86(3):553-563.

Deb, G.K., Kabir, M.A., Miraz, M.F.H., Hossain, S.M.J., Afroz, M.F., Nahar, T.N. and Mostofa,.M.K. 2018.In vivo study of follicular statistics in Red Chittagong Cattle of Bangladesh. Bang. J. Anim. Sci. 47 (1):47-50.

Donald, M.c.1980. Veterinary Endocrinology and Reproduction. Lea and Febiger, Philadalphia, 274-398.

Farin, P.W., Youngquist, R.S., Parfet, J. R. and Garverick, H.A. 1992. Diagnosis of 
luteal and follicular ovarian cysts by palpation per rectum and lineararray ultrasonography in dairy cows. J. Am. Vet. Med. Assoc. 200:1085-1089.

Gustafsson, H. and Emanuelson, U. 2002. Characterisation of the repeat breeding syndrome in Swedish dairy cattle. Acta Veterinaria Scandinavica. 43(2):115-125.

Hassan, M.M. 2017. Prevalence and risk factors of repeat breeding in cows. MS Thesis, Department of Surgery and Obstetrics, Faculty of Veterinary Science, Bangladesh Agricultural University, Mymensingh, Bangladesh.

Iqbal Hasan ,Mir. Md., Maruf Hassan, Md., Mohanta ,Rupam Chandra., Miah,Md. Abu.Haris., Rashid, Mohammad Harun-Or. and Juyena, Nasrin Sultana. 2018 . A comparative study on productive, reproductive and ovarian features of repeat breeder and normal cyclic cows in the selected areas of Bangladesh. J.Adv.Vet.Anim.Res. 5(3):324-331.

Islam, M.R. 2012.Treatment outcomes in postpartum anoestrus cows guided by transrectal ultrasonography, MS Thesis, Department of Surgery and Obstetrics, Faculty of Veterinary Science, Bangladesh Agricultural University, Mymensingh, Bangladesh..

Islam, M.S., Deb, G.k., Habib, M.A., Ershaduzzaman, M., Ali, Md. Yousuf., Kabir, M.H., Akter, Most. Sumona., Aktaruzzaman, M., Salah Uddin, M., Rahman, S.M. and Afroz, M.F.2018. Effect of feeding concentrate on the reproductive efficiency of repeat breeder cows at Baghabari milk shed area. Asian J. Med. Biol. Res. 4 (1), 137-140.
Islam, Mohammed Sirajul., Deb, G.K., Nurunnahar, Talukder., Ershaduzzaman, Md., Habib, M.A., Ali, Md. Yousuf., Kabir, Md. Humayun., Yousuf, Md. Abu., Afroz, Most. Farhana and Yeasmin ,Tahera.2017. Identification of possible causes of repeat breeding in dairy cows at Baghabari milk shed areas, Sirajgonj, Bangladesh. Asian J. Med. Biol. Res. 3 (2), 186-190.

Kesler, D.J. and Garverick, H.A. 1982. Ovarian cysts in dairy cattle: A review. J. Anim. Sci. 55: 1147-1159.

Kesler, D.J., Elmore, R.G., Brown, E.M. and Garverick, H.A..1981. Gonadotropin Releasing Hormone Treatment of Dairy Cows with Ovarian Cysts I. Gross Ovarian Morphology and Endocrinology. Theriogenology 16:207-217.

Khair, A., Alam, M.M, Rahman, A.K.M.A., Islam, M.T., Azim, A. and Chowdhury, E.H. 2013. Incidence of reproductive and production diseases of cross-bred dairy cattle in BanglaJournal of Veterinary Medicine. 11(1):31-36.

Lafi, S.Q. and Kaneene, J.B. 1992. Epidemiological and economic study of the repeat breeder syndrome in Michigan dairy cattle. I. Epidemiological modelling. Prev. Vet. Med. 14: 87-98.

Lequin, R. 2005. Enzyme immunoassay (EIA)/enzyme-linked immunosorbent assay (ELISA). Clin. Chem. 51: 2415-2418.

Lucy, M.C. 2001. Reproductive loss in high-producing dairy cattle: where will it end? J. Dairy Sci. 84: 12771293.

Macmillan, K.L., Lean, I.J. and Westwood, C.T. 1996. The effects of lactation on the fertility of dairy cows. Aust. Vet. Journ. 73: 141-147. 
Meléndez, P., Bartolomé, J., Archbald ,L.F. and Donovan, A. 2003. The association between lameness, ovarian cyst and fertility in lactating dairy cows. Theriogenology 59, 927-937.

Meneghetti, M., SáFilho, O.G., Peres, R.F.G., Lamb, G.C. and Vasconcelos, J.L.M.2009. Fixed-time artificial insemination with estradiol and progesterone for Bos indicus cows I: basis for development of protocols. Theriogenology 72(2):179-189.

Nath BK, Das BC, Bari MS, Rahman MA.2014. Prevalence and risk factors of repeat breeding in commercial dairy farms of Chittagong district of Bangladesh. Inter..J.Nat. Sci.. 4(1):21-27. Bangladesh Ortega, H.H., Marelli, B.E., Rey, F., Amweg, A.N., Díaz, P.U., Stangaferro, M.L.and Salvetti, N.R. 2015. Molecular aspects of bovine cystic ovarian disease pathogenesis. Reproduction 149: R251-R264.

Perry, G.A., Smith, M.F., Lucy, M.C., Green, J.A., Parks, T.E., MD, MacNeil., Roberts, A.J. and Geary, T.W.2005. Relationship between follicle size at insemination and pregnancy success. Proceedings of the National Academy of Sciences of the United States of America. 102(14):5268-5273.

Pesánteza, J.L., Ortiza, O. and Hernández-Ceróna, J.2016. Incidence of ovarian follicular cysts and their effect on reproductive performance in dairy cows: A case study in Mexico. Arch Med Vet 48, 289-291.

Peter, A.T. 2004. An update on cystic ovarian degeneration in cattle. Reprod Domest Anim 39, 1-7.
Rahman, M.A. 1996.Endometritis in cows: Diagnosis and selection of antimicrobials. MS Thesis, Department of Surgery and Obstetrics, Faculty of Veterinary Science, Bangladesh Agricultural University, Mymensingh, Bangladesh..

Roche, J.F., Mackey, D. and Diskin, M.D. 2000. Reproductive management of postpartum cows. Anim. Reprod. Sci., 60-61: 703-712.

Royal, M.D., Darwash, A.O., Flint, A.P.F., Webb, R., Woolliams, J.A. and Lamming, G.E. 2000. Declining fertility in dairy cattle: changes in traditional and endocrine parameters of fertility. Anim Sci., 70: 487-501.

Silviu, Ionut BORȘ., Iulian, IBĂNESCU., Șteofil, CREANGĂ. and Alina BORȘ.2018. Reproductive performance in dairy cows with cystic ovarian disease after single treatment with buserelin acetate or dinoprost. J. Vet. Med. Sci. 80(7): 1190-1194.

Vanholder, T.G., Opsomer, Kruif, A.de .2006. Aetiology and pathogenesis of cystic ovarian follicles in dairy cattle: a review. Reprod Nutr Dev 46, 105-119.

Vasconcelos, J.L.M., Pereira, M.H.C., Meneghetti, M., Dias,C.C., SáFilho, O.G., Peres, R.F.G., Rodrigues, A.D.P., Wiltbank, M.C. 2013.Relationships between growth of the preovulatory follicle and gestation success in lactating dairy co.

Ali M.Z., Sultana S, Rahman M.T. and M.S. Islam.2013. Economics of Fertility Management of Small Holding Dairy Farms in Bangladesh. Iranian J. Applied. Anim. Sci. 3 (3):509-512. 